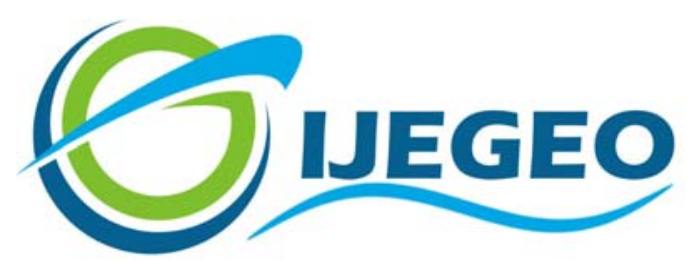

International Journal of Environment and Geoinformatics (IJEGEO) is an international, multidisciplinary, peer reviewed, open access journal.

\title{
Spatio-Temporal Dynamics of Sediment yield across the Imo River Basin SE Nigeria
}

\section{Amara Ethel UZOR-TOTTY, Charles Uwadiae OYEGUN}

\author{
Chief in Editor \\ Prof. Dr. Cem Gazioğlu \\ Co-Editors \\ Prof. Dr. Dursun Zafer Şeker, Prof. Dr. Şinasi Kaya, \\ Prof. Dr. Ayşegül Tanık and Assist. Prof. Dr. Volkan Demir
}

Editorial Committee (August 2020)

Assos. Prof. Dr. Abdullah Aksu (TR), Assit. Prof. Dr. Uğur Algancı (TR), Prof. Dr. Bedri Alpar (TR), Prof. Dr. Lale Balas (TR), Prof. Dr. Levent Bat (TR), Prof. Dr. Paul Bates (UK), İrşad Bayırhan (TR), Prof. Dr. Bülent Bayram (TR), Prof. Dr. Luis M. Botana (ES), Assos. Prof. Dr. Gürcan Büyüksalih (TR), Prof. Dr. Nuray Çağlar (TR), Prof. Dr. Sukanta Dash (IN), Dr. Soofia T. Elias (UK), Prof. Dr. A. Evren Erginal (TR), Assoc. Prof. Dr. Cüneyt Erenoğlu (TR), Dr. Dieter Fritsch (DE), Prof. Dr. Çiğdem Göksel (TR), Prof.Dr. Lena Halounova (CZ), Prof. Dr. Manik Kalubarme (IN), Dr. Hakan Kaya (TR), Assist. Prof. Dr. Serkan Kükrer (TR), Assoc. Prof. Dr. Maged Marghany (MY), Prof. Dr. Michael Meadows (ZA), Prof. Dr. Nebiye Musaoğlu (TR), Prof. Dr. Masafumi Nakagawa (JP), Prof. Dr. Hasan Özdemir (TR), Prof. Dr. Chryssy Potsiou (GR), Prof. Dr. Erol Sarı (TR), Prof. Dr. Maria Paradiso (IT), Prof. Dr. Petros Patias (GR), Prof. Dr. Elif Sertel (TR), Prof. Dr. Nüket Sivri (TR), Prof. Dr. Füsun Balık Şanlı (TR), Prof. Dr. Uğur Şanlı (TR), Duygu Ülker (TR), Prof. Dr. Seyfettin Taş (TR), Assoc. Prof. Dr. Ömer Suat Taşkın (US), Dr. İnese Varna (LV), Dr. Petra Visser (NL), Prof. Dr. Selma Ünlü (TR), Assoc. Prof. Dr. İ. Noyan Yılmaz (AU), Prof. Dr. Murat Yakar (TR), Assit. Prof. Dr. Sibel Zeki (TR) 


\title{
Spatio-Temporal Dynamics of Sediment yield across the Imo River Basin SE Nigeria
}

\author{
Amara Ethel Uzor-Totty * (iD) Charles Uwadiae Oyegun (iD) \\ Gebze Technical University, Department of Geomatics Engineering, 41400, Kocaeli, TR \\ Department of Geography and Environmental Management, Faculty of Social Sciences, University of Port Harcourt, PMB 5323, Choba, Port \\ Harcourt, Rivers State, Nigeria. $1 *$ \\ * Corresponding author: AE Uzor-Totty \\ Received 11 Nov 2019 \\ E-mail: auzortotty@gmail.com;charles \\ Accepted 01 May 2020
}

How to cite: Uzor-Totty and Oyegun (2020). Spatio-Temporal Dynamics of Sediment yield across the Imo River Basin

SE Nigeria, International Journal of Environment and Geoinformatics (IJEGEO), 7(2), 184-190. DOI: 10.30897/ijegeo.645611

\begin{abstract}
Soil and water are the two main natural resources that sustain human existence on earth. Proper monitoring and maintenance of these resources are done on the basin level. The IRB drains an area of 7,951.03 km2. The basin has a mean annual discharge of $120 \mathrm{~m} 3 / \mathrm{sec}$ and generates significant surface runoff and sediment. The study aim was to evaluate the sediment yield across IRB using the Soil and Water Assessment Tool (SWAT) model. SWAT is a watershed-based, semi-distributed hydrologic model for simulating hydrological processes at different spatial scales. The model utilized digital elevation model DEM to extract the river network, basin delineation, and sub-basin division. The sub-basins were further divided into hydrological response unit HRU at a threshold of 5\% slope, 5\% the land use, and 5\% soil. Harmonized soil data and two land-use data of 1995 and 2010 were used to simulate the sediment yield across IRB. The study result shows an increase in sediment yield of 0.73 t/ha from1995 to 2010 . Sub-basin 10 has the highest sediment yield during the two periods; September and October are the months with the highest sediment yield.
\end{abstract}

Keywords: River basin; SWAT model; Sediment yield

\section{Introduction}

Sediment yield is the amount of sediment generated with a basin over a while; it is also the amount that will enter the surface water or reservoir located downstream of the basin (Morris and Fan, 1998). Sediment yield modeling has attracted the attention of many researchers but lack of data, resources and widely accepted methods to predict and or estimate sediment yields are some of the difficulties facing research in this direction (Ndomba et al., 2008b, 2009; Shimelis et al., 2010). The impacts of land-use change on river basin hydrology and sediment yield are interrelated to climate impacts. In Nigeria, several studies have reported that human activities are the main cause of soil erosion (Madu, 2004; Lorkua and Ikyernum, 2004). Also, land use and topography have shown great influence on soil erosion (Imeson et al., 1998; Seeger and Ries, 2008), as well as soil physical parameters, especially soil texture and surface characteristics which are used to determine soil susceptibility to erosion (Cammeraat and Imeson, 1998; Mackel and Walter, 1911). Other outcomes of erosion include sediment yield in streams and reservoirs, reduction of water quality status, and the deposition of toxic materials on farmland (Poesen and Hook, 1997).

Drainage basin models that can simulate soil erosion and sediment yield can be grouped into three broad categories: empirical, conceptual (partly empirical/mixed), and physically-based model (Fernanda, et al., 2005). The empirical soil erosion models are statistical and are based on data from filed observations such as annual soil erosion and precipitation, vegetation cover, soil types, topography, land use types, tillage styles, and conservation measures. Due to the simple structure, these models are easy to apply (Merritt, et al., 2003). Their choice also depends on the availability of data, scale, and objective of the research. Models of this category include Universal Soil Loss Equation (USLE) (Wischmeier and Smith, 1965), the Modified Universal Soil Loss Equation (MUSLE) Williams, (1975), or the Revised Universal Soil Loss Equation (RUSLE) (Renard, et al., 1997, Algan et al., 1999). Other are kinematic runoff and erosion model KINEROS2, MEDRUSH a product of the Mediterranean desertification and land use Project, European soil erosion model (EUROSEM), Agricultural nonpoint source pollution model (ANGPS). Water erosion prediction project model (WEPP) and the Soil water assessment tool (SWAT). The model was developed and maintained by the Agricultural Research Services of the US department of agriculture (USDA) to compute longterm runoff and nutrient export from the rural watershed. The robustness and interdisciplinary nature of SWAT have gained the model international acceptance which can be seen in the numerous publication in international SWAT conferences, and other scientific meetings and journals (Gassman, et. al; 2007; Moazzam et al., 2018). The model is also very flexible, Kim et al; 2008 demonstrates that an integrated SWAT-MODFLOW is capable of simulating a Spatio-temporal distribution of groundwater recharge rates, aquifer evapotranspiration, and groundwater levels. It also enables an interaction between the saturated aquifer and channel reaches. This 
interaction played an important role in the generation of groundwater discharge in the basin, especially during the low flow period.

Monitoring sediment movement at a basin level is timeconsuming and expensive when using the physical observation method. Thus the use of geospatial techniques requires the use of drainage basin models in monitoring. This study is important at this time for effective erosion and flood-prone areas monitoring and prioritizing areas that need urgent attention. The choice of Imo River Basin (IRB), is as a result of previous works carried out which showed that erosion by water in the IRB has been identified to be a major cause of gully erosion and sediment yield especially in the northern region of the basin and siltation of river in the south
(Ofomata, 1980). This study aims to evaluate the dynamics of sediment yield in IRB and to provide data for appropriate land and water development policymaking.

\section{Materials and Methods}

\section{Study Area}

The IRB is located in the Eastern region of Nigeria, (Figure 1) cutting across the States of Imo, Abia, and Rivers. It is bounded on the east by Ebonyi, Cross River, and Akwa-Ibom states and in the West by the Niger River, in the North by Enugu and Anambra States, and in the South the Atlantic Ocean.

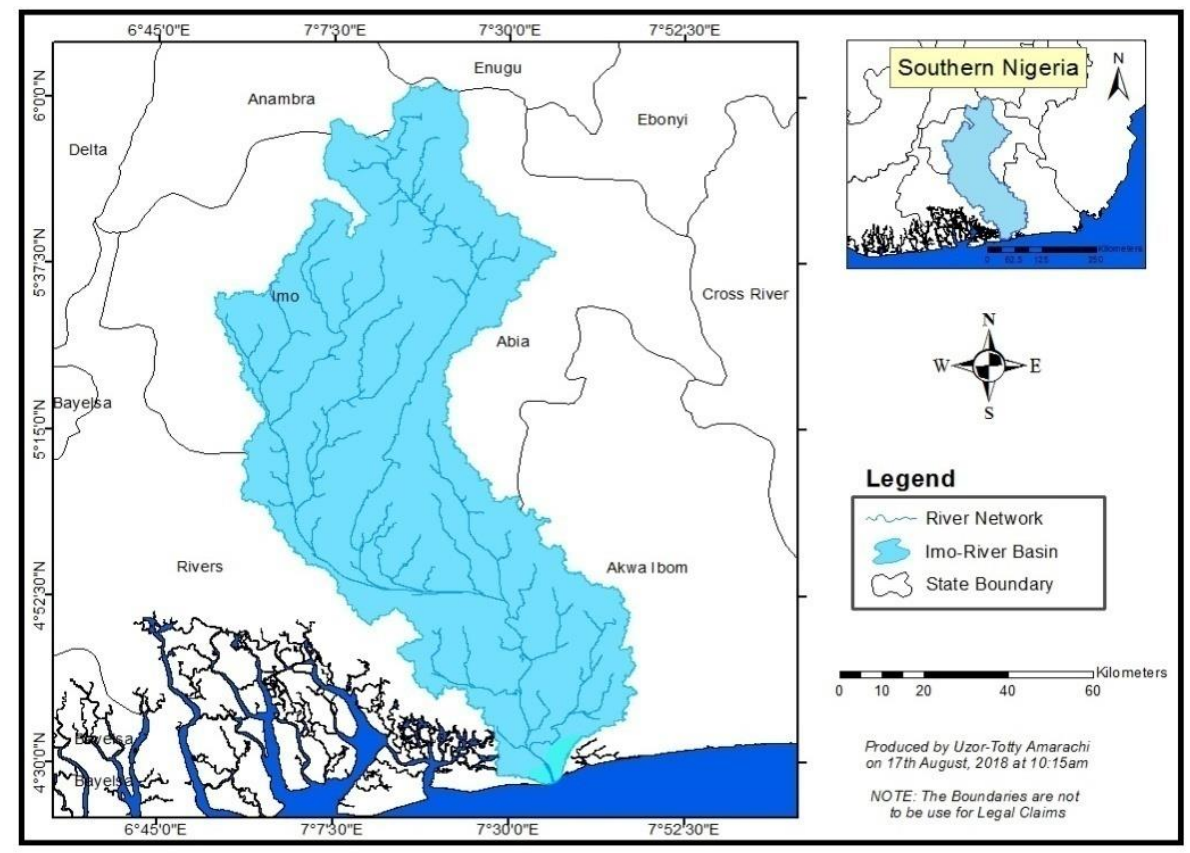

Fig. 1: Extent and Location of IRB.

The highest point on the study area is located in the northern part with an elevation of $255 \mathrm{~m}$ above sea level while the lowest point is towards the south with an elevation of $3 \mathrm{~m}$ above sea level. The climatic condition of the area can be classified as consisting of tropical monsoon (Am) and tropical rainforest (Af) according to Koppen climatic classification. Rainfall amount ranges from over $2500 \mathrm{~mm}$ in the southern part of the basin to about $1500 \mathrm{~mm}$ annually towards the northern borders with an average number of rain days ranging between 120 - 152 rain/days annually. Rainfall intensities are high and often above $50 \mathrm{~mm} / \mathrm{h}$ with short interval intensities over $100 \mathrm{~mm} / \mathrm{h}$ (Igwe, 2012; Chiemelu, et al., 2019). Rainfall often comes between March and lasts till October and a two-week break in August. However, in some years the basin experiences either an early onset of rain with early cessation or late-onset with late cessation. The average maximum and minimum air temperature of the basin ranges from $30 \mathrm{C}$ and $21 \mathrm{C}$ in the south and $31 \mathrm{C}$ and $22 \mathrm{C}$ in the north while the hottest months are January and March (NIMET). The relative humidity is about $85 \%$ in the south and $65 \%$ in the north. The average annual sunshine hours and solar radiation are about $5 \mathrm{hrs}$ and $4.2(\mathrm{MJ} / \mathrm{m} 2$ day) respectively.

The basin has two prominent features Udi-OkigweArochukwu at the north-eastern part and the AwkaUmuchu- Umuduru sedimentary cuestas at the northwestern side (Uma, 1989). The IRB sits on layers of sedimentary rocks of about 5480m thick and with ages ranging from Upper Cretaceous to Recent (Uma, 1986). The deposition of these sedimentary rocks is related to the opening of the South Atlantic Ocean and the formation of the rift-like Benue Trough of Nigeria in the Mesozoic (Schlumberger, 1985). According to Ijeh and Onu (2013), $80 \%$ of the basin consists of Coastal plain sand, which composes of non-hardened sediments that constitute the Benin and Ogwashi-Asaba formations, with alluvial deposits at the estuary, south of the basin. The remaining 20\% shows a series of younger sedimentary rock units when moving southwestward.

\section{SWAT Model Description}

The SWAT model is a physically-based distributed model designed to predict the impact of land 
management practices on water, sediment, and agricultural chemical yields in large complex watersheds with varying soil, land use, and management conditions over long periods ( Neitsch, et al; 2012). The recent version of the SWAT model uses the simplified stream power equation of Bagnold (1977) to route sediment in the channel. The maximum amount of sediment that can be transported from a reach segment is a function of the peak channel velocity. Sediment transport in the channel network is a function of two processes, degradation, and aggradation (i.e. deposition), operating simultaneously in the reach (Neitsch et al., 2005). SWAT subdivides a basin into sub-basins connected by a stream network and further delineates each sub-basin into hydrological response units (HRUs) consisting of homogenous land use and soils. The model also simulates other physical processes at the basin level, such as hydrological routines inland and routing phases, vadose zone processes (infiltration, evaporation, plant uptake, lateral flows, and percolation), and groundwater flows (Zhang et al; 2009). At the HRU level evapotranspiration from various plant and soil, surface runoff, sediment, water yield, and non-point loads are calculated and summed up to sub-basin level. The Modified Universal Soil Loss Equation (MUSLE) is used by the model to compute soil erosion by computing sediment yields from each subbasin and routing the sediment yields to the basin outlet.

$S Y L D=11.8 *\left(Q_{\text {surf }} * q p\right)^{0.56} * K * L S * C * P * C F R G$ (Eq. 1)

\section{Where}

SYLD is the sediment yield to the stream network in metric tons; Qsurf is the surface runoff volume in $\mathrm{mm}$, qp is the peak flow rate in $\mathrm{m} 3 / \mathrm{s} ; \mathrm{K}$ is the soil erodibility factor; LS is the slope length and gradient factor; $\mathrm{C}$ is the cover management factor and can be derived from land cover data; $\mathrm{P}$ is the erosion control practice factor which is a field-specific value, and CFRG is the coarse fragment factor

Also, the hydrological cycle uses water balance equation in SWAT:

$$
S W_{t}=S W_{0}+\sum_{i=1}^{t}\left(R_{i}-Q_{i}-E T_{i}-P_{i}-Q R_{i}\right)
$$

Where:

$\mathrm{SW}_{\mathrm{t}}$ is the final soil water content $\left(\mathrm{mm} \mathrm{H}^{2} \mathrm{O}\right)$; $\mathrm{SW}_{\mathrm{o}}$ is the initial soil water content on day $\mathrm{i}\left(\mathrm{mm} \mathrm{H}^{2} \mathrm{O}\right)$; $\mathrm{t}$ is the time (days); $\mathrm{R}_{\mathrm{i}}$ is the amount of precipitation on day $\mathrm{i}(\mathrm{mm}$ $\left.\mathrm{H}^{2} \mathrm{O}\right) ; \quad \mathrm{Q}_{\mathrm{i}}$ is the amount of surface runoff on day $\mathrm{i}(\mathrm{mm}$ $\mathrm{H}^{2} \mathrm{O}$ ); ET, is the amount of evapotranspiration on day $\mathrm{i}$ $\left(\mathrm{mm} \mathrm{H} \mathrm{H}^{2} \mathrm{O}\right) ; \mathrm{P}_{\mathrm{i}}$ is the amount of water entering the vadose zone from the soil profile on day $\mathrm{i}\left(\mathrm{mm} \mathrm{H}^{2} \mathrm{O}\right)$, and $\mathrm{QR}_{\mathrm{i}}$ is the amount of return flow on day $\mathrm{i}\left(\mathrm{mm} \mathrm{H}^{2} \mathrm{O}\right)$.

\section{Data Set}

SWAT input data includes weather, topographic slope), soil, and land use. Weather data for the study was obtained from the Nigerian Meteorological Agency (NIMET), the weather parameters include precipitation, solar radiation, relative humidity, sunshine, wind, and air temperature. The land use (30m resolution) for 1995 was obtained generated from the Ministry of Agriculture Forestry Unit while 2010 was obtained National Geomatics Center of China. Elevation data for the study area was derived from the Shuttle Radar Topographic Mission (SRTM), a 30m resolution dataset from the U.S. Geological Survey. The data were extracted in the Georeferenced Tagged Image File Format (GeoTIFF); the horizontal datum is the World Geodetic System 1984 (WGS84 - Geographic) while the vertical datum is the Earth Gravitational Model 1996 (EGM 96) ellipsoid; and the vertical unit is the meter (USGS, 2016). The DEM was used to calculate the slope, streamflow direction, and stream order. The DEM and the soil type map are shown in Figures 2 and 3, respectively.

The harmonised world soil data produced by Food and Agricultural Organization (FAO), International Institute of Applied System Analysis (IIASA), World Soil Information (ISRIC), Institute of Soil Science-Chinese Academy of Science (ISSCAS) and Joint Research Centre of the European Commission (JRC) was used. Seven soil classes were found in the study area (Figure 3 ). $52.87 \%$ of the basin is covered by Xanthis Ferraisols which covers $4,203.71 \mathrm{~km}^{2}$ of the basin and is the largest soil type in the basin, Dystric Fluvisols type covered $395.96 \mathrm{~km}^{2}$, Thionic Fluvisols covers 616.20 $\mathrm{km}^{2}$. The Dystric Nitosols are of three types and they covered 2,611.12. $\mathrm{km}^{2}$ of the basin while Dystric Regosols covered $27.83 \mathrm{~km}^{2}$ of the total basin area. However, water bodies cover an area of $96.21 \mathrm{~km}^{2}$. SWAT2012 version was used to compile the SWAT input files. The IRB was divided into 173 sub-basins and 1338 HRUs based on a threshold of 5\% soil, 5\% slope, and 5\%land use.

\section{Results}

\section{Hydrologic Response to Sediment yield Change}

Hydrological response places an important role in the movement of sediment within a basin; the Imo River which is the main river system is a fourth-order stream with a drainage density of $0.17 \mathrm{~km} / \mathrm{km}^{2}$ and relatively flat topography at a scale of $1: 5 \mathrm{~km}$. The ArcSWAT model simulation process was carried out using Land use of 1995 for hydrological processes for 1995 and the 2010 Land uses for the hydrological processes for 2010. The results are shown in Table 1. 




Fig. 2. Sub-basins from DEM

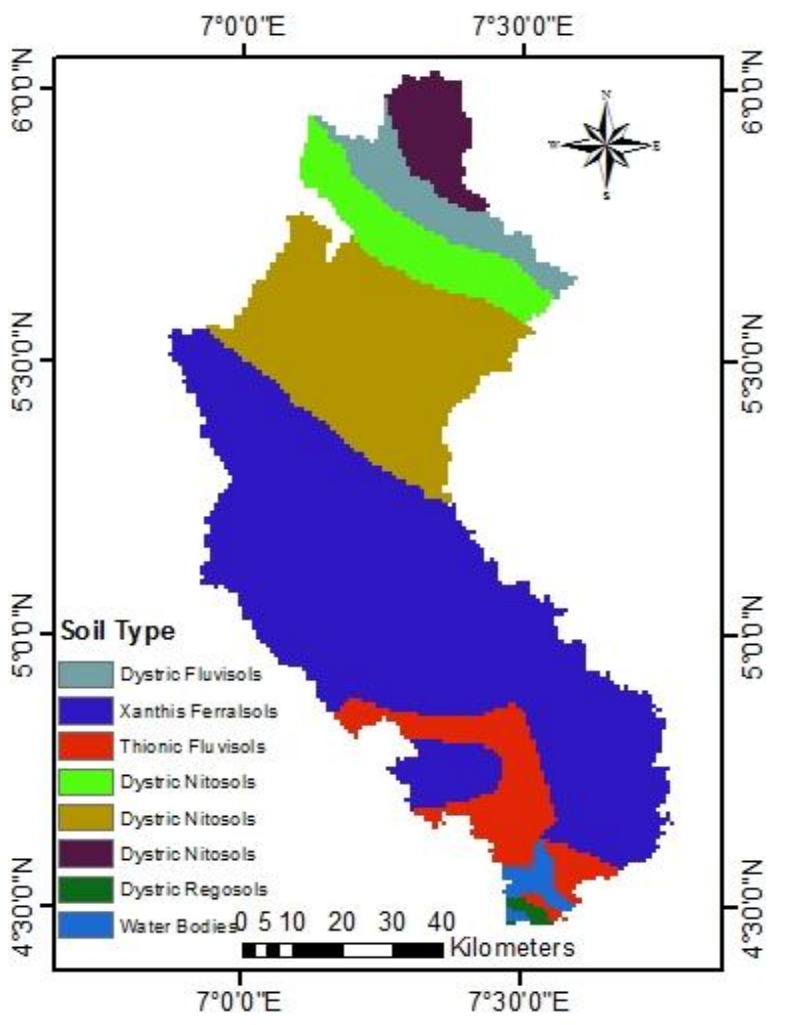

Fig. 3. Soil type

Table 1: Mean Annual hydrological summaries in the IRB for 1995/2010.

\begin{tabular}{llllllllll}
\hline Year & PREC & SURQ & LATQ & GWQ & SW & ET & WYLD & SYLD & LATE \\
\hline 1995 & 252.87 & 37.34 & 1.92 & 120.37 & 132.04 & 80.97 & 165.99 & 1.20 & 130.11 \\
2010 & 266.36 & 46.93 & 1.98 & 124.59 & 130.43 & 81.90 & 177.57 & 1.93 & 133.59 \\
Change & 13.49 & 9.59 & 0.06 & 4.22 & -1.61 & 0.93 & 11.58 & 0.73 & 3.48 \\
\hline
\end{tabular}

Notes: * PREC: Average amount of precipitation ( $\mathrm{mm}$ ), SURQ: Average amount of surface runoff, LATQ: Lateral flow contribution for the year (mm), GWQ: Groundwater contribution for the year (mm), LATE: Water percolation past bottom of soil profile in basin for the year (mm), SW: Amount of water stored in soil profile for the year (mm), ET: Actual evapotranspiration in basin for the year $(\mathrm{mm})$, WYLD: Water yield for the year $(\mathrm{mm})$, and SYLD: Sediment yield in basin for the year (t/ha).

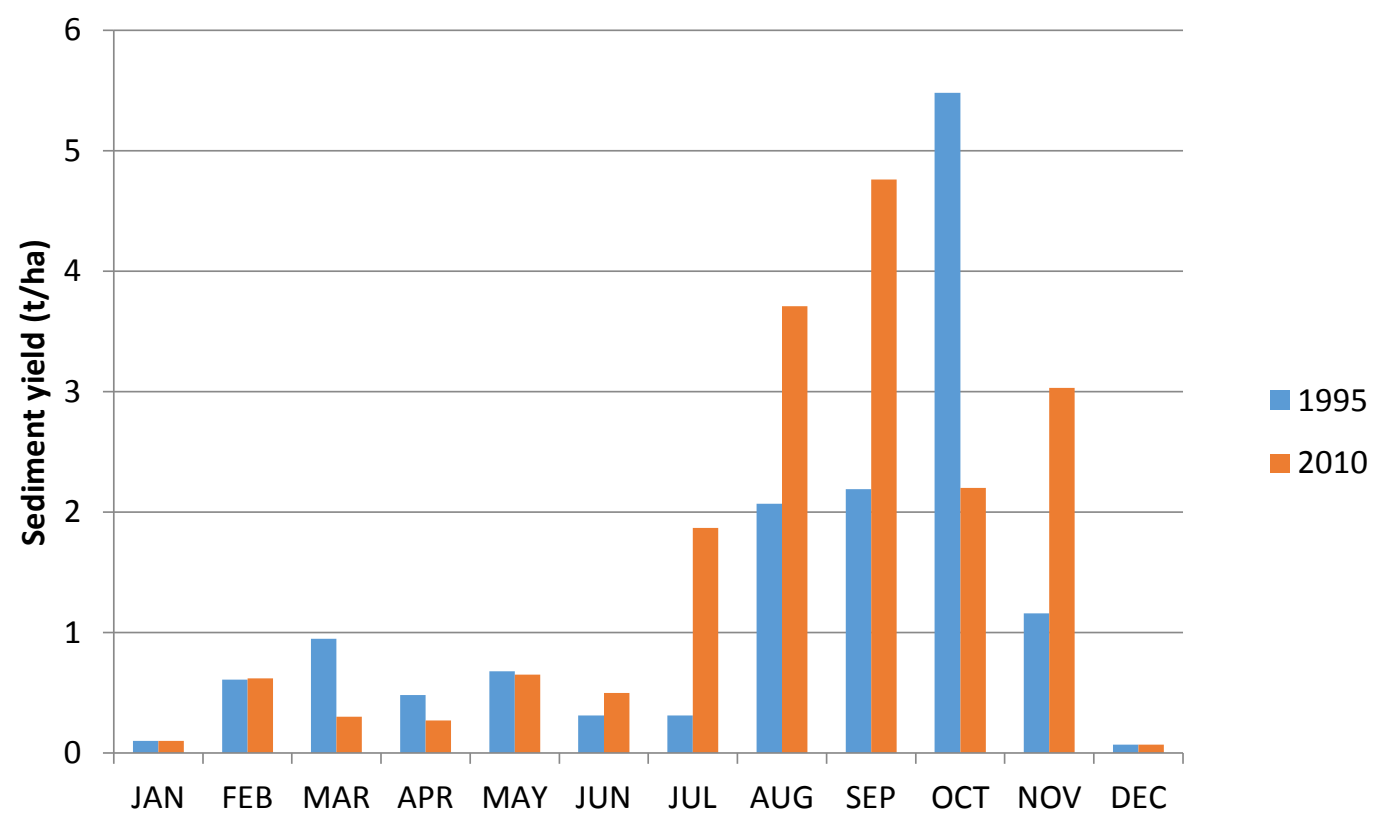

Fig. 4: Monthly sediment yield in the IRB 
The annual hydrological result shows that a $2.6 \%$ increase in rainfall was able to generate an $11.4 \%$ increase in surface runoff which caused a remarkable change of $23.3 \%$ increase which is $0.73 \mathrm{t} /$ ha of sediment across the IRB from 1995 to 2010 . This reveals that an increase in rainfall can increase surface runoff as well as sediment yield in the IRB.

\section{Temporal variation of sediment yield in the IRB}

December and January of 1995 and 2010 recorded the same value of sediment yield of $0.07 \mathrm{t} / \mathrm{ha}$ and $0.10 \mathrm{t} / \mathrm{ha}$ respectively in the two years under investigation. October recorded the highest sediment yield for 1995 with rainfall of $409.75 \mathrm{~mm}$ while September recorded the highest for 2010 with $487.75 \mathrm{~mm}$ rain. 1995 showed a relatively low sediment yield of below 2.2 t/ha across the months apart from October recording $5.48 \mathrm{t} / \mathrm{ha}$ which is $38 \%$. In 2010, September recorded the highest value of $4.76 \mathrm{t} / \mathrm{ha}$ representing $26 \%$ of total sediment yield for the year. There was an increase of $3.67 \mathrm{t} / \mathrm{ha}$ in the total annual sediment yield between 1995 and 2010 .

Ten sub-basins out of 173 sub-basins showed a relatively high sediment yield change, sub-basin 2 recorded the highest change of $2.46 \mathrm{t} / \mathrm{ha}$ of sediment from 1995 to 2010. The lowest change occurred in sub-basin 3 with a change of $0.66 \mathrm{t} / \mathrm{ha}$ of sediment as seen in Table 2. The increase in sediment can be associated with an increase in rainfall. Furthermore, during the two years under investigation sub-basin, 10 recorded the highest sediment yield with an increased chance of $0.78 \mathrm{t} / \mathrm{ha}$ from 1995 to $2010.70 \%$ of the sub-basins with the highest sediment yield change are located in the northern region.

Table 2: Largest change of sediment yield among Sub-basins.

\begin{tabular}{lllll}
\hline Sub-basin & Area $\left(\mathbf{k m}^{2}\right)$ & SYLD 1995 & SYLD 2010 & Change \\
\hline $\mathbf{1}$ & 47.49 & 5.11 & 6.80 & 1.69 \\
$\mathbf{2}$ & 28.22 & 5.65 & 7.09 & 2.46 \\
$\mathbf{3}$ & 29.82 & 6.86 & 7.52 & 0.66 \\
$\mathbf{6}$ & 35.83 & 3.89 & 5.13 & 1.24 \\
$\mathbf{7}$ & 34.98 & 3.19 & 4.25 & 0.78 \\
$\mathbf{1 0}$ & 48.58 & 7.72 & 8.50 & 1.24 \\
$\mathbf{2 6}$ & 66.76 & 1.07 & 2.31 & 1.27 \\
$\mathbf{8 8}$ & 10.66 & 4.54 & 5.81 & 1.22 \\
$\mathbf{9 4}$ & 50.06 & 4.04 & 5.26 & 0.73 \\
\hline $\mathbf{1 0 2}$ & 56.31 & 2.37 & 3.10 & 0.78 \\
\hline
\end{tabular}
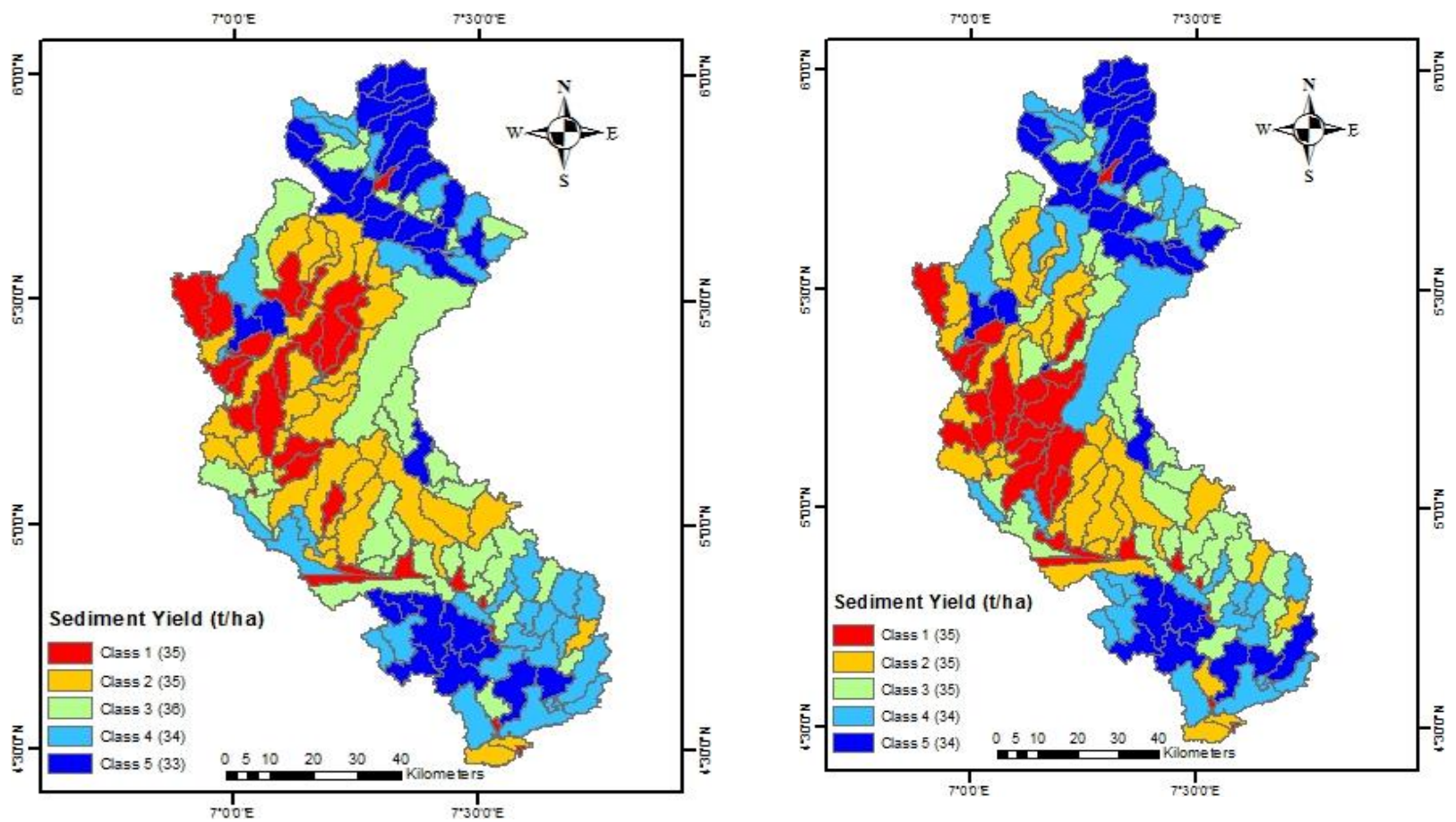

Fig. 5. Spatial distribution of sediment yield 1995(a) and 2010(b).

\section{Spatial variation of sediment yield in the IRB}

The spatial distribution of sediment yield across IRB in 1995and 2010 was classified using the quintile method, class 5 which represents those with the highest volume of sediment has 33 and 34 sub-basins in 1995 and 2010 respectively and are more around the northern region while class 1 which represents those with the lowest volume of sediment yield are located towards the western region with 35 sub-basins for the two periods under investigation. The southern region has a combination of class 5, 4 and 3, while the eastern region is a combination of class 3 and 4 and 5 , the presence of 
class 5 in the south is because that is the location of the outlet of the basin. Sediment yield of $23.3 \%$ occurred with a $2.6 \%$ increase of rain, this implies that there is a tendency of having more sediment yield in the IRB if there is more rain in the region. Land-use changes could also contribute to the increase of $0.73 \mathrm{t} / \mathrm{ha}$ experienced from 1995 to 2010.

\section{Discussion and Conclusions}

Sustainable natural resource management, which is a sub-goal under Goal 13 of the SDGs, should be the main focus of policymakers in the IRB. Soil and water degradation and the after effect needs prompt and effective monitoring to achieve sustainability. The model runs for different land use period are performed on similar weather conditions as the annual rainfall is about $252.87 \mathrm{~mm}$ and $266.36 \mathrm{~mm}$ for 1995 and 2010, respectively. According to the model results, it is necessary to prescribe appropriate soil and water conservation practices to control sedimentation problems in the Imo River Basin. The variation in sub-basin sediment yield will help prioritize any best management practices (BMP) implementation areas. The sediment load spatial distribution showed that a larger amount of sediment is from the northern part (Okigwe environs) of the basin which also corresponds with heavy sediment removal and gully formations recorded from that area from other studies (Ofomata 1973, 1978 and 1980). This study has shown that SWAT can model the temporal and spatial variation of sediments yield and is capable of identifying areas within the basin with high sediment yield. This provides a useful guideline for formulating policies and developing plans to counteract erosion effects which the basin is known for and to achieve sustainable land development within the basin. High erosion areas may be easily identified within the basin using the model output results at the HRU level. Subsequent land development should avoid such areas because of the need to adequately protect them with appropriate conservation strategies. Human activities within the IRB deserve more attention due to their impact on soil and water loss. To avoid illegal development activities, the government should formulate laws and regulations to limit indiscriminate use of land within the basin.

\section{References}

Algan O, Gazioğlu C, Çağatay N, Yücel ZY, Gönençgil B. (1999). Sediment and water influxes into the Black Sea by Anatolian rivers. Zeitschrift für Geomorphologie 43: 61-79.

Bagnold, RA., (1977). Bedload transport in natural rivers. Water Resour. Res. 13:303-312.

Cammeraat, LH., Imeson, AC. (1998). Deriving indicators of soil degradation from soil aggregation studies in southeastern Spain and southern France. Geomorphology, 23: 307-321 http://dx.doi.org/10.1016/S0169-555X

Chiemelu, N., Nkwunonwo, U., Okeke, F., Ojinnaka, O. (2019). Geospatial Evaluation of Wind Energy Potential in the South-East and South-South Sections of Nigeria. International Journal of Environment and Geoinformatics, 6(3), 244-253. DOI: 10.30897/ ijegeo.549796.

Fernanda Maria de Lima Paiva, Richarde Marques da Silva, Celso Augusto Guimarães Santos (2005) Study of vegetal cover influence on experimental erosion plots by runoff-erosion modeling. Sociedade and Natureza, Uberlândia, Special Issue, 235-242.

Gassman, P.W.; Reyes, M.; Green, C.H., Arnold, J.G (2007). The soil and water assessment tool: historical development, applications, and future directions. Trans. ASABE, 50: 1211-1250.

Igwe CA (2012) Gully Erosion in Southeastern Nigeria: Role of Soil Properties and Environmental Factors. A Journal Earth and Planetary Sciences, DOI: $10.5772 / 51020$

Ijeh, I. B., Onu, N.N. (2013). Assessment of pollution levels of groundwater in parts of Imo River Basin, South Eastern Nigeria. International Journal of Water Resources and Environmental Engineering. 5(4): 194-202.

Imeson, A. C., Lavee, H., Calvo A., Cerda A. (1998). The erosional response of Calcerous soils among a climatological gradient in southeastern Spain. Geomorphology, $24: 3-16$ http://dx.doi.org/10.1016/S0169-555X.

Kim, N.W.; Chung, I.M.; Won, Y.S. Arnold, J.G (2008). Development and application of the integrated SWAT-MODFLOW model. J. Hydrol. 356: 1-16.

Lorkua S. A., Ikyernum, J. (2004). Population pressure land-use intensity and environmental degradation in Book of abstracts of the 46th annual conference of the Association of Nigeria geographers held at Benue state university Makurdi.

Mackel, R., Walther, D. (1994). A field guide to soil erosion and its management implication of crusted soil in the Sahel. Soil Use and Management, 15: 123127.

Madu, J.A. (2001). Population and environmental problem. In Ofamata, G. E. K., and Phil Eze, P. O. (Eds.), Geographical Perspectives on Environmental Problems and Management in Nigeria (p. 80). Ibadan, Nigeria: Jameo Enterprises.

Merritt, W., R. Letcher, A. Jakeman. (2003). A review of erosion and sediment transport models. Environmental Modelling and Software 18:761-799.

Moazzam, M, Vansarochana, A, Rahman, A. (2018). Analysis of flood susceptibility and zonation for risk management using frequency ratio model in District Charsadda, Pakistan. International Journal of Environment and Geoinformatics, 5(2), 140-153. DOI: $10.30897 /$ ijegeo.407260.

Morris, G. Fan, J., (1998). Reservoir sedimentation Handbook: Design and Management of Dams, Reservoirs, and Catchment for Sustainable use. McGraw-Hill, New York. Chapter 7:7.1-7.44.

Ndomba, PM., Mtalo, F., Killingtveit, A., (2009). Estimating Gully Erosion Contribution to Large Catchment Sediment Yield Rate in Tanzania. Journal of Physics and Chemistry of the Earth 34: 741 - 748. DOI: $10.1016 /$ j.pce.2009.06.00.

Ndomba, P.M., Mtalo, F.W., Killingtveit, A. (2008b). A Guided SWAT Model Application on Sediment 
Yield Modelling in Pangani River Basin: Lessons Learnt. Journal of Urban and Environmental Engineering, 2(2): 53-62. DOI:10.4090/juee.2008

Neitsch, SL., Arnold, JG., Kiniry, JR., Williams, JR. (2005). Soil and Water Assessment Tool Theoretical Documentation Version 2005. Grassland, Soil, and Water Research Laboratory; Agricultural Research Service 808

Neitsch, SL., Arnold, JG.; Kiniry, JR., Williams, JR (2012). Soil and Water Assessment Tool Theoretical Documentation, version 2012; Texas AandM University: College Station, TX, USA.

Ofomata, GEK. (1973). "Village erosion at Ozuitem, East Central State of Nigeria". Ikenga. 11: 64-74.

Ofomata, GEK. (1978). "Man as a factor of Soil Erosion in Southeastern Nigeria". Eco-Trop.. 1: 143-154.

Ofomata, GEK. (1980). "Perspectives on Environmental Deterioration in Nigeria". The Tropical Environment.1: 6-19.

Renard, K.G., G. Foster, G. Weesies, D. McCool D. Yoder. (1997). Predicting soil erosion by water: A guide to conservation planning with the revised universal soil loss equation (RUSLE). United States Department of Agriculture (USDA). Washington, DC, USA.

Schlumberger (1985). Well evaluation conference Nigeria: Schlumberger Technical Services Inc. Schlumberger (1985). Well evaluation conference Nigeria: Schlumberger Technical Services Inc.

Seeger, M., Ries, JB. (2008). Soil degradation and soil surface process intensities of abandoned field in Mediterranean mountain environments. Land Degrade Development, 19:488-501. http://dx.doi.org/10.1002/ldr.854

Shimelis G. Setegn, Bijan Dargahi, Ragahavan Srinivasan, Assefa M. Melesse (2010). Modeling of sediment yield from Anjani-Gauged Watershed, Ethiopia Using SWAT Model. Journal of the American Water Resources Association, 46, ( 3): 514-526.

Uma KO (1986). Analysis of Transmissivity and Hydraulic Conductivity of Sandy Aquifers of the Imo River Basin. Unpl. Ph.D. Thesis, University of Nigeria, Nsukka.

Uma KO (1989). An appraisal of the groundwater resources of the Imo River Basin, Nigeria. J. Min. Geol. 25(1 and2):305-331.

Van Rompaey, A.J.J.; Govers, G. Puttemans, C (2002). Modeling land-use changes and their impact on soil erosion and sediment supply to rivers. Earth Surf. Proc. Land. 27: 481-494.

Williams, J.R. (1975).Sediment routing for agricultural watersheds. Water Resources Bulletin. 11(5):965974.

Wischmeier, W. Smith, D. (1965). Predicting rainfall erosion losses from cropland east of the rocky mountains. agricultural handbook, no. 282. US Department of Agriculture, Washington, DC

Yan, B.; Fang, N.F.; Zhang, P.C. Shi, Z.H (2013). Impacts of land-use change on watershed streamflow and sediment yield: An assessment using hydrologic modeling and partial least squares regression. $J$. Hydrol. 484: 26-37.

Yang, SK.; Jung, WY.; Han, WK. Chung, IM (2012). Impact of land-use changes on stream runoff in Jeju Island, Korea. Afr. J. Agric. Res.7: 6097-6109.

Zhang, X., Srinivasan, R. Van Liew, M (2009). Approximating SWAT model using artificial network and support vector machine. J. Am. Water Resour. Assoc.45: 460-474. 